\title{
EDITORIAL
}

\section{SOME FICTIONAL PROTOTYPES}

Most of us when we read books project ourselves into the personalities of their heroes and heroines so that when they succeed we rejoice and when they meet with misfortune we too suffer. In consequence most of us welcome information on the originals of any fictional characters since this adds so much to their reality.

As some readers were kind enough to tell us that they enjoyed our recent Editorial on Robert Munro-the prototype of these splendid 17th Century warriors Captain Dugald Dalgettie and Decimus Saxon-we felt that a few notes on some members of our Service who have been the prototypes of famous fictional characters might also be of interest.

We have space to touch on but three such prototypes viz. those of Dr. Slammer of the 98th (Dickens "The Pickwick Papers"), Dr. Watson (Conan Doyle's Sherlock Holmes stories) and Dr. O’Grady (André Maurois' " Les Silences du Colonel Bramble ”).

\section{Dr. Slammer of the 98th}

There can be few readers who have not laughed at the part played by the fire eating regimental surgeon of the 98th (Dr. Slammer) in the duel scene in the "Pickwick Papers $\because$ For years we had wondered who his prototype was-for so vivid a character demanded an original - but we only learnt of his identity this winter when in the course of conversation with Mrs. J. Byam-Shaw the latter told us that he was Mathew Lammert (No. 1941 in Drew's Roll). Mrs. Byam-Shaw further provided us with notes on Lammert which we reproduce below:-

Lammert was the second husband of Dickens' aunt and the father of James Lammert of Warren's Blacking Warehouse. The Lammerts lived in Chatham where Dickens was brought up. Dr. William Fyffe (who had known him at Fort Pitt) had this to say of him in later years, "I know this gentleman well; he was a kind, hospitable, warm hearted man; but he was very tetchy on the subject of having been immortalised by the great novelist. Everyone knew of it; but none dared to call him "Slammer" as the penalty might have been serious!"

Several points are worth noting-firstly the similarity between "Lammert" and "Slammer", secondly that Drew's Roll shows him as serving in his last years in the Army with the 91st Foot-not a long step on to the 98th and thirdly that as he had seen a lot of action-Egypt, Copenhagen, Walcheren and Peninsular (1809-14) where he was wounded, it is small wonder that he was such a fire-eater!

\section{Dr. Watson}

Watson is probably the most famous of all doctors in fiction, and his prototype none other than Alexander Francis Preston (No. 6081 in Drew's Roll).

The case of Preston being Watson or Watson being Preston (whichever way you look at it) has been most skilfully presented by Mr. F. H. Mende of Charlo tte, N. Carolina, United States of America in an article in 1971. Thanks to the Author's courtesy we have a copy in our Historical Library which members are free to consult as we have no intention of stealing Mr. Mende's thunder by reproducing his arguments here. 
Preston was born on the 23rd May 1842 and graduated at Dublin (A.B., M.B.) in 1863. He entered the Army in 1863 and held both regimental and staff appointments. He retired in 1902 in the rank of Surgeon General having held the temporary appointment of D.G.A.M.S. He died on 24th July 1907.

By far the most exciting period of his career was in the Second Afghan War where at the Battle of Maiwand (1880) as Medical Officer to the Royal Berkshire Regiment (the 66th) he was seriously wounded and was one of the few officers to survive. Readers will recall Dr. Watson's reference to both the Battle of Maiwand and to his wounds received there. Again, it is interesting to note the similarity of "Preston " and "Watson" which parallels "Lammert" and "Slammer".

One final point-during our hunt (while wearing the hat of the Curator, R.A.M.C. Historical Museum) for information for Mr. Mende's article, we found frequent references to Preston's Narrative of his experiences at Maiwand and indeed it is one of the principle sources for accounts of the battle. For four years we searched for it and earlier this year we found it-in a GHQ India publication of 1881 . We have sent a copy to Mr. Mende and hope for a second paper on Preston (or should it be Watson?).

\section{Dr. O'Grady}

We made the acquaintance of Slammer, Watson and O'Grady and of them all O'Grady was the one we admired most because of his courage, kindness and tolerance. Just as with Slammer we felt that O'Grady too must have an original but unlike Slammer we did not have to wait 50 years to find the answer but merely 20 for it was while serving on the staff of Major-General Sir Percy Tomlinson during World War II that the latter, knowing our weaknesses for literature and history, told us that Brigadier W. G. James, C.B.E., M.C., and Bar, M.D. (His Consultant in Psychiatry in the Middle East) was the model of O'Grady.

Brigadier James graduated (St Mary's Hospital) in 1912 and obtained his M.D. (London) and was at once caught up in the First World War serving throughouf on the Western Front. It was while serving as an R.M.O that he made the acquaintance of André Maurois who was to immortalise him. For his bravery he gained an M.C. and bar. On demobilisation he returned to civil life and to his chosen field of Psychiatry in which he so greatly distinguished himself.

During World War II he again joined the Army and was Consultant in Psychiatry in the Middle East (1940-43) and later Consultant in Psychiatry to the Army at Home (1943-45). After the War he returned to civil life and died in 1968.

Thanks to the kindness of the Editor of The Lancet we fittingly conclude this brief account by the remarks made 'by J.D.W.P.' in his Obituary (Lancet 26 October 1968).

"It was in the mud of Flanders that James's life long friendship with André Maurois began. In his deeply perceptive study of wartime human relations, in which James was the leading figure, Maurois depicted these characteristics of the man which were to endure throughout his life-his own unswerving courage and his tolerance of frailty in others, his dislike of cant, his cheerfully pessimistic philosophy, his acute observation of the world and mankind, his constant kindness and generosity of spirit, the affection and loyalty given to his colleagues and his sensitivity and skill with his patients". 
There can be few doctors who have earned so splendid and moving a tribute. We would express our thanks to Mrs. Byam-Shaw whose encyclopaedic knowledge of and enthusiasm for the byways of the 19th Century scene not only produced Lammert but the idea for this editorial, to Mr. Mende who produced Preston for us and to the Editor of the "Lancet" for permitting us to quote from his journal.

Birthday Honours List-1976

C.B. Major-General J. McGhiE, M.D., F.R.C.Psych, D.P.M.

O.B.E. Colonel W. C. Moffat, M.B., Ch.B., F.R.C.S., D.T.M.\&H.

M.B.E. Major J. PotTeR, T.D., R.A.M.C. (T.A.V.R.)

R.R.C. Lieutenant-Colonel M. Chamberlarn, Q.A.R.A.N.C.

A.R.R.C. Major M. C. PetTegree, Q.A.R.A.N.C. Major V. J. Smith, Q.A.R.A.N.C. 